\title{
Does religiosity influence venture capital investment decisions?
}

\begin{abstract}
Theories on contextual behavior (e.g., social norm, self-identity, and legitimacy theories) suggest that the religiosity of the geographical area in which an organization operates influences its behavior. Using a sample of 91,020 VC investments in the U.S., we study whether religiosity influences VC investment decisions. Based on prior literature that finds a positive relation between religiosity and risk aversion, we posit that VCs located in more religious counties make less risky investments. We find that VCs located in more religious areas are more likely to be involved in staging and syndication and have a greater propensity to invest in later and expansion stages of portfolio companies. Taken together, our results suggest that VCs located in religious counties tend to be more risk averse.
\end{abstract}

JEL Classification: D83, G20, G24, L14, M13.

Keywords: Religiosity, Venture Capital, Risk aversion. 


\section{Introduction}

Venture capitalists (VCs) are financial intermediaries that combine technological competence with financial skills to provide financial and management support to startup firms (Gorman and Sahlman, 1989; Gompers and Lerner, 1999; Manigart et al., 2002; Sahlman, 1990; Sapienza et al., 1996; Wright and Lockett, 2003; Andrieu and Groh; 2018).

The VC industry has grown dramatically over the past three decades. From 1980 to 1990, VC investments in the U.S. increased from USD \$610 million to \$2.3 billion (National Venture Capital Association, 2012). By 2010, total VC investment in the U.S. totaled approximately $\$ 30$ billion. Moreover, revenue from formerly backed VC companies comprised $21 \%$ of U.S. GDP, and these firms employed $11 \%$ of the U.S. private sector workforce (National Venture Capital Association, 2012). By the third quarter of 2016, about \$56 billion was invested across 6,000 companies in the U.S. (PitchBook-NVCA Venture Monitor, 2016).

Nevertheless, VC investments tend to be high risk (Ewens and Rhodes-Kropf, 2015). Sahlman (2010) reports that $85 \%$ of VC returns come from $10 \%$ of investments, and, from 1987-2012, only $12.8 \%$ of VC investments achieved an Initial Public Offering (IPO). The investment risk stems mainly from agency problems that can result from asymmetric information between VCs and entrepreneurs (Knight, 1921; Kaplan and Strömberg, 2004; Bertoni and Groh, 2014). Specifically, in VC investments, it is common for the VC to have relatively limited information about the growth potential of the firm. This is due to limited historical financial information, as well as the expensive and time-consuming process of gathering data to overcome any potential information deficits (Groh et al., 2010).

It can be difficult for VCs to accurately gauge founding entrepreneurs' ability to lead startups. This also increases the complexity of projecting future performance and investment risk (Berger and Frame, 2007; Berger and Udell, 1998; Freel, 1999, 2000, 2007; Neus and 
Walz, 2005; Bertoni and Groh, 2014). The fact that entrepreneurs usually have more complete information than VCs leads to high adverse selection risk, which is typically borne by the VC (Cumming and Johan, 2008, 2013; Hain et al., 2016).

Kaplan and Schoar (2005) report that, in contrast to other asset classes, such as mutual funds, VCs also tend to have persistent performance. Their success tends to be replicated in the next funds they manage. This ability of some VC funds to consistently produce top-performing investments suggests there is something unique and largely time-invariant about VC funds. In this paper, we examine whether one such factor is religiosity.

To test our hypothesis, we use a comprehensive dataset of U.S. VC investments, consisting of 91,020 observations for the 1980-2014 period. Similarly to prior studies (e.g., Alesina and La Ferrara, 2000; Hilary and Hui, 2009; Dyreng et al., 2012; Adhikari and Agrawal, 2016a; Chircop et al., 2017), we source data on religiosity from the Association of Religion Data Archives (ARDA). We use the number of adherents and the number of denominations in the county in which the $\mathrm{VC}$ is headquartered as our two measures of religiosity.

Given that risk-taking is unobservable, we use the propensity for a VC to be involved in the staging, syndication, and timing of VC investments as our three measures of risk taking. Prior literature has shown that staging mitigates agency problems, as more information about the startup is gathered over time, and the VC retains the option to abandon the project if it fails to meet strategic targets (e.g., Admati and Pfleiderer, 1994; Gompers, 1995; Kaplan and Strömberg, 2003, 2004; Wang and Zhou, 2004; Tian, 2011).

Note that VC firms often seek other VC partners when investing in entrepreneurial companies. This process is referred to as syndication. It enables the VC firm to share investment risk with other VC firms while enjoying joint payoffs, because there may be an increase in the alignment of interests (Wright and Lockett, 2003; Manigart et. al., 2006; Hain 
et al., 2016; Casamatta and Haritchabalet, 2007; Groh and von Liechtenstein, 2011; Hirsch and Walz, 2011). Finally, by investing in a startup at a later stage, the VC can effectively mitigate the problem of adverse selection, because it will have more information about the entrepreneur and the firm's financial performance (Gompers, 1995; Wang and Zhou, 2004; Bienz and Walz, 2010; Cumming and Johan, 2013; Bertoni et al., 2015). We find that VCs that are headquartered in more religious areas have a higher likelihood of being involved in staging, syndication, and of investing in startups at a later stage.

We subject our results to a series of robustness tests. First, we check whether our results are driven by reverse causality, where more religious risk-averse entrepreneurs are seeking investments from religious VCs. Second, we include VC firm fixed effects to ensure that our observed results are not driven by cross-sectional variation in VC firms. Third, we conduct a series of falsification tests to ensure our results are not driven by portfolio firm religiosity. Fourth, we undertake tests to confirm that our results are not influenced by our econometric choices, such as the regression models used to run our main specification, or the way we calculate our religiosity measures. Fifth, we test whether our results are sensitive to VC investment strategy. Sixth, we check whether the observed results are driven by the clustering of VC activity in specific counties. Finally, to mitigate the possibility that our results are driven by an omitted variable that is correlated with both VC religiosity and VC investments, we examine how religiosity affects investments. To this end, we use the subsample of VC firms that changed counties during our sample period. Inferences from all of these tests suggest that our results are robust to the abovementioned specifications.

In additional analyses, we find that the influence of religiosity on VC investment decisions varies cross-sectionally as a function of the agency conflict between the VC and the startup firm. We also find that VCs located in areas with more Protestants than Catholics tend to be more risk averse in their investment decisions. 
Our contribution to the prior literature is twofold. First, we add to the literature on the influence of religiosity on investment decision making. The extant literature has shown that religiosity influences corporate investments (Hilary and Hui, 2009), innovation (Adhikari and Agrawal, 2016a), and mutual fund investments (Shu et al., 2012). In a similar vein, we also examine the effect of religiosity on investment decision making, but our setting is clearly different. Unlike companies or mutual funds, VCs tend to be lightly regulated and exposed to higher investment risk. They invest in startups, which generally have limited or no availability of historical data to project the future performance of the applied technology (Berger and Frame, 2007; Berger and Udell, 1998, 2002; Freel 1999, 2000, 2007). The lack of qualitative and quantitative information required to evaluate a startup exposes the $\mathrm{VC}$ to significant adverse selection risk.

On the other hand, in contrast to companies or mutual funds, VCs can seek capital investments from sophisticated institutional or accredited investors. These professional investors are less likely to allow personal values to influence their investment decisions. Hence, it is ex ante unclear to what extent religiosity influences VC investment decisions.

Second, to the best of our knowledge, we are the first to study the effect of the local environment on VC investment decisions. Some prior studies (e.g., Hilary and Hui, 2009; Shu et al., 2012) have shown that characteristics of the local environment can influence firm decisions. However, no study has yet examined the effect of characteristics of the local environment on VC investment decisions. This is somewhat surprising, given that the paucity of historical information about startups can increase the subjectivity of the VC investment decision making process.

In this respect, Duffner et al. (2009) and Bottazzi et al. (2016) provide valuable empirical evidence on the importance of trust in venture capital investing. Specifically, they show that trust reduces doubts about investment decisions ex ante and can provide a good ex 
post basis for efficient and effective communication between the $\mathrm{VC}$ and the entrepreneur. Various studies have documented the relation between religiosity and trust (e.g., Hain et al., 2016; Chuah et al., 2016). However, no study has yet examined the relation between the religiosity of the geographic area in which the VC operates and its investment decision making. This study fills this void.

The remainder of this paper proceeds as follows. In section 2, we briefly review the prior literature and develop our hypothesis. In section 3, we establish our sample period, and describe our measures of VC risk taking and religiosity. Section 4 presents our main results, while section 5 shows the results for our robustness tests. In section 6 , we discuss further analyses. Section 7 concludes.

\section{Hypothesis development}

In this study, we examine whether the religiosity of the geographic area in which a VC operates influences its investment decision making. Similarly, to Shu et al. (2012), we posit that: 1) VC religiosity influences decision making, and 2) VC religiosity is consistent with that of the geographical location in which it operates.

With respect to the first premise, prior literature has shown that religiosity and religious affiliation influence occupational choice, organizational behavior, managerial decisions, and financial market behavior (Hilary and Hui, 2009; Kumar et al., 2011; Audretsch et al., 2013; Chircop et al., 2017). These effects stem from the link between individual religiosity and individuals' own levels of risk aversion (Miller and Hoffmann, 1995; Barsky et al., 1997; Iannaccone, 1998; Lehrer, 2004; Benjamin et al., 2016; Liu, 2010; Dohmen et al., 2011; Noussair et al., 2013; Audretsch et al., 2013). Specifically, Malinowski (1925) and Miller and Hoffmann (1995) suggest that risk-averse people manage losses and fear through participation in religion, while Hilary and Hui (2009) suggest that more anxious individuals are likely to seek comfort through church attendance (Rokeach, 1968; Gasper and Clore, 1998). 
The effect of religiosity on economic decision making has been studied in numerous settings. For example, religiosity has been shown to influence the decision to pursue entrepreneurial activities (Audretsch et al., 2013), corporate investments (Hilary and Hui, 2009), the use of option grants (Kumar et al., 2011), the incidence of accounting irregularities (McGuire et al., 2011), the propensity to undertake earnings management (Grullon et al., 2009; Dyreng et al., 2012), the propensity to undertake tax avoidance activities (Boone et al., 2012), patent innovations (Adhikari and Agrawal, 2016a), bank risk taking (Adhikari and Agrawal, 2016b; Chircop et al., 2017), and mutual fund risk taking (Shu et al., 2012).

Furthermore, religiosity may influence decision making through its effect on trust. In an experimental study, Chuah et al. (2016, p. 295) find evidence "that religion operates indirectly through social identities and religious affiliation which are used as a basis for discrimination in trust games." For mutual funds and corporate investments, trust may be less important, because objective information about prospective investments is usually readily available. However, for VC investments, trust is of paramount importance (Hain et al., 2016). In contrast to other types of investing, VCs invest in startups, where historical information about the applied technology and the firm itself can be limited. Trust may partly fill this lacuna in available information.

Bottazzi et al. (2016) distinguish between two types of trust: personalized and generalized. Personalized trust develops as a consequence of repeat interactions between two persons and can be regarded as the set of beliefs a person holds about the behavior of another person. Conversely, generalized trust can be thought of as the beliefs an individual has about a random group of identifiable individuals. The distinction between the two is particularly relevant in the context of VC investment decisions. When making an initial investment decision about a new startup, the VC does not know the entrepreneur. Thus, the relation is influenced 
by generalized trust. Once the initial investment has taken place, and the VC has repeatedly interacted with the entrepreneur, personalized trust develops.

The second premise underlying our investigation is that VC religiosity is consistent with that of the geographical location in which it operates. This assertion is based on theories related to contextual behavior. For example, social norm theory suggests that the religious norms of the environment in which the VC operates influence the VC regardless of whether the VC partners are themselves religious. This is because the norms of the local environment are an important component of the society within which the VC partners live and operate (Kohlberg, 1984; Sunstein, 1996; Cialdini and Goldstein, 2004; McGuire et al., 2011).

Moreover, social identity theory (e.g., Tajfel, 1978; Hogg and Abrams, 1988) suggests that individuals are influenced by the local environment in which they operate through social interactions, in which people share their identities with each other. In this ambit, Schneider (1987) and Hilary and Hui (2009) argue that people are attracted to situations where they think they will fit in. Olson and Perl (2011) and Lim (2013, p. 396) find that "the religious composition of local areas predicts the religious composition of one's intimate friendship network."

Finally, legitimacy theory suggests that firms need to establish congruence between the social norms implied by organizational activities, and the norms of the environment in which the firm is established. Legitimacy gaps, emanating from conflicts between the two sets of norms, may result in stakeholders withholding resources from the firm, thus hampering its operations (Dowling and Pfeffer, 1975; Chircop et al., 2017).

On the other hand, the lack of regulatory oversight over VC investments and heightened financial incentives may moderate the influence of religiosity on risk taking behavior (Jia and Wang, 2017). Unlike other collective investment vehicles, such as listed companies and mutual funds, VC firm investors are comprised of institutions and accredited or high net worth 
individuals, collectively known as sophisticated investors. VCs tend to be lightly regulated, and therefore there is no definitive investment mandate (or, rather, risk profile) that VCs must adhere to other than what is agreed upon between the investors and managing partners (Cumming and Johan, 2008). Furthermore, compared to other financial intermediaries, VCs have significant financial incentives, because they are typically paid a portion of the excess returns (Cumming and Johan, 2008, 2013; Jia and Wang, 2017).

The flexibility in making investment decisions, together with the ability to take concentrated risks, likely motivates VCs to focus on profit-maximizing investment decisions. Thus, the influence of religiosity on VC investment decisions may be minimal.

Note that many VC firms operate from several locations, often spread out across different counties. Most VCs empower the investment professionals located in these offices to carry out deal identification and due diligence, but the decision to invest is still made by the committee of managing partners that operates from the VC headquarters. If VC investment decision making is made in locations outside the headquarters, and if the VC partners located at headquarters have limited influence, then headquarters religiosity is unlikely to impact VC decision making.

Finally, given that VC partners tend to be professionals who invest significant personal wealth in their own funds (Cumming and Johan, 2006; Jia and Wang, 2017), it remains unclear whether they allow their religious beliefs to influence their financial judgments.

In summary, prior literature linking religiosity to risk aversion and theories related to contextual behavior suggest that VCs headquartered in areas that are more religious are more risk averse in their decision making. In contrast, the nature of $\mathrm{VC}$ firms may moderate any possible relationship between religiosity and VC investment decisions. Hence, it is an empirical question whether the negative relationship between religiosity and risk taking observed in the extant literature applies to VCs. 


\section{Data and variables}

\subsection{Sample selection}

Our dataset merges several databases. We extract data for completed investment deals, where both the VC firm and the company are located in the U.S., from VentureXpert Thomson Financial. We exclude investments where dollar total investment, number of investors, number of rounds, and information on the first round of investment is missing. Data for county characteristics comes from Woods \& Poole Economics, while data on religiosity comes from the Association of Religion Data Archives' (ARDA) ${ }^{1}$ decennial surveys. Our final sample contains 91,020 VC firm investment observations for the 1980-2014 period. ${ }^{2}$

In Table 1, we present the sample distribution by year. The number of $\mathrm{VC}$ investments increases steadily until 2000, when it stands at 7,029; it then drops after the so-called "dotcom" bubble bursts. The number rises again in the years prior to the recent financial crisis, until, in 2008, it stands at 5,055. After the financial crisis, the number drops again rather precipitously, and in 2014, the last year of our sample, we have 2,048 VC investment transactions. Average total funds invested per transaction by VC firms in a portfolio company per year are $\$ 41,403$ (column (3) of Table 1), and the average deal had 25 investors (column (4) of Table 1) and 6 financing rounds (column (5) of Table 1). Furthermore, $84 \%$ of investment rounds on average involved syndicates (column (6) of Table 1).

[Table 1 here]

\subsection{Religiosity and control variables}

Our measure of religiosity comes from ARDA's decennial surveys. ${ }^{3}$ The dataset provides information on the number of recognized religious denominations, and the number of

\footnotetext{
${ }^{1}$ This data is publicly available at http://www.theARDA.com.

${ }^{2}$ Our sample is comparable to that in other studies, such as, e.g., Nahata (2008).

${ }^{3}$ We recognize that these surveys suffer from self-selection bias, since religious denominations self-select to participate in these surveys. However, the alternative surveys by Gallup suffer from the same problem, as denominations also self-select to participate.
} 
adherents to these denominations in each county. We source our data from the ARDA surveys undertaken in 1980, 1990, 2000, and 2010. In contrast to other studies (e.g., Alesina and La Ferrara, 2000; Hilary and Hui, 2009; Dyreng et al., 2012; Adhikari and Agrawal, 2016a, 2016b; Gao et al., 2017), we obtain data for missing years through linear interpolation. This increases the power of our tests but assumes a linear change in our variables over time.

We compute two measures of religiosity. The first, ADHERENTS, follows prior literature (e.g., Hilary and Hui, 2009; Gao et al., 2017), and is computed as the total number of adherents to any recognized religious denomination, scaled by the population of the county. The second, DENOMINATIONS, is the number of recognized denominations per 1,000 population in each county. The Pearson correlation between these two measures is around 16\%, and suggests they capture different dimensions of religiosity. Specifically, the first measure captures the quantity of people in each county that follow a religion, while the second measure captures the variety of religious denominations in a county.

\subsection{VC firm investment risk measures}

We construct three distinct measures of VC investment risk. To this end, we rely on prior literature regarding established risk-mitigating measures used by VCs in their investments (e.g., Admati and Pfleiderer, 1994; Gompers, 1995; Kaplan and Strömberg, 2003; Wright and Lockett, 2003; Wang and Zhou, 2004; Manigart et al., 2006; Casamatta and Haritchabalet, 2007; Tian, 2011; Cumming and Johan, 2008, 2013; Bertoni et al., 2015; Hain et al., 2016). The first measure captures the degree to which a VC firm is involved in staging, the process whereby the $\mathrm{VC}$ firm divides its total committed financing to the portfolio company into several financing rounds. Staging is an important instrument for controlling for investment risk, because the VC firm retains the option to pursue or abandon further investment in a company. To capture VC involvement in staging, we construct a variable, NUMBER OF ROUNDS, that captures the number of financing rounds provided to the company by the VC firm. 
Our second measure of firm investment risk captures the degree to which the VC is involved in syndication, which refers to the cooperation of several VC firms in financing a deal. Syndication allows a VC firm to share investment risk among many firms. Thus, our second measure, NUMBER OF INVESTORS, captures the number of investors in the company. VC firms also decide in what stage of company development they will invest. Seed and earlystage investments pose a greater risk than investments in later and expansion stages. We, therefore, create a third measure of risk, LATER OR EXPANSION, that captures whether VC funding is at the later or expansion stage of company development.

\subsection{Control variables}

As in previous studies (e.g., Bottazzi et al., 2016), ${ }^{4}$ we control for VC firm, portfolio company, and county characteristics in our model. In particular, we control for deal characteristics that are measured at the level of VC firm and portfolio company pairs, such as whether the VC firm is an independent private equity firm, its size, and age. ${ }^{5}$ Furthermore, we include controls for the industry in which the company operates, and for whether the company is seeking seed or early-stage financing. We also control for demographic characteristics at the county level, such as population size, age, employment, and education. We also include variables to proxy for economic conditions such as income and gross regional product at the county level. Finally, we include company, county, and year fixed effects. We provide more details on the variables in Appendix Table AI.

\subsection{Summary statistics}

Table 2 shows the summary statistics for our sample period, 1980 $\square 2014$. Mean ADHERENTS is 0.48 , suggesting that, on average, $48 \%$ of each county's population adheres to

\footnotetext{
${ }^{4}$ Note that Bottazzi et al.'s (2016) research methodology allows them to control for certain VC and company characteristics for which we do not have readily available data.

${ }^{5} \mathrm{VC}$ size and age indirectly control for VC partner ability, because larger and older VC firms are more likely to have VC partners of higher ability.
} 
a religious denomination. Mean DENOMINATIONS is 0.57 , suggesting, on average, there is one religious denomination per 2,000 people in a county.

The average age of VC firms in our sample is $27[=\exp (3.33)]$, and $83 \%$ of them are independent firms. Approximately $70 \%$ of the portfolio companies are information technology firms, while $19 \%$ are medical firms. Only $11 \%$ of portfolio companies received their first financing at the seed stage, and over $26 \%$ received it at an early stage. Average distance between VC firm and portfolio company is 40 miles [= $\exp (2.69)]$.

In terms of demographic controls, the mean population of the county in which the firm and company are headquartered is $953[=\exp (6.86)]$ thousand and $1,187[=\exp (7.08)]$ thousand, respectively. Average population age in VC firm and portfolio company counties is $36[=\exp (3.57)]$ and $35[=\exp (3.55)]$ years, respectively, while average population in employment is $671[=\exp (6.51)]$ thousand in the firm's county, and $820[=\exp (6.71)]$ thousand in the company's county. Average annual income is $\$ 50,000$ (in 2009 dollars). The gross regional product (GRP) of the VC firm and company county is $\$ 67,507$ [= exp(11.12)] million and $\$ 81,634[=\exp (11.31)]$ million in 2009 dollars, respectively.

[Table 2 here]

\section{Results}

This section presents our main findings for the relationship between religiosity and VC investment characteristics. We proxy for VC firm risk-taking behavior using the three $\mathrm{VC}$ investment measures: 1) "staging," the number of financing rounds in which the VC participates, 2) "syndication," the number of participants in each financing round, and 3) the stage of company development at which the $\mathrm{VC}$ investment takes place.

We test for the influence of religiosity on VC risk taking using the specification expressed in Eq. (1):

$$
\text { RISK_TAKING }=\alpha+\beta R E L I G I O S I T Y+\text { Controls }+ \text { County F.E. }+ \text { Year F.E. }+\varepsilon
$$


where RISK_TAKING is one of our three measures of risk taking: NUMBER OF ROUNDS, NUMBER OF INVESTORS, and LATER OR EXPANSION. We define the dependent variables, NUMBER OF ROUNDS and NUMBER OF INVESTORS, as the natural log of 1 plus the number of financing rounds and the natural $\log$ of 1 plus the number of investors, respectively, in order to estimate Eq. (1) as an Ordinary Least Squares (OLS) regression. ${ }^{6}$ LATER OR EXPANSION is an indicator variable that equals 1 if the $\mathrm{VC}$ investment takes place in a later or expansion phase of the firm, and 0 otherwise. We run Eq. (1) as a linear probability regression when LATER OR EXPANSION is the dependent variable. ${ }^{7}$ RELIGIOSITY is either ADHERENTS or DENOMINATIONS. We include the controls discussed earlier, county and year fixed effects.

Panel A of Table 3 reports the results when ADHERENTS is our measure of religiosity. We find that ADHERENTS is associated with reduced VC risk taking, as shown by the positive and significant association with our dependent variables. Specifically, the coefficient on ADHERENTS when the dependent variable is either NUMBER OF ROUNDS (coeff: $0.133 \mathrm{t}$ stat: 1.74) or NUMBER OF INVESTORS (coeff: 0.210 t-stat: 1.65 ) is significant at the $10 \%$ level. It is significant at the 5\% level when LATER OR EXPANSION (coeff: 0.133 t-stat: 2.30) is the dependent variable. The economic effects of these results suggest that a 1-standard deviation increase in ADHERENTS increases NUMBER OF ROUNDS by 0.013 and NUMBER OF INVESTORS by 0.021 . These increases correspond to approximately $2.4 \%$ of the standard deviation of NUMBER OF ROUNDS and NUMBER OF INVESTORS. Similarly, a 1-standard deviation in ADHERENTS increases the propensity of investing in the LATER OR EXPANSION stages by $2.7 \%$.

\footnotetext{
${ }^{6}$ As robustness tests, we performed a Poisson and a negative binomial regression when the number of rounds and the number of investors are unlogged. The inferences from these results are similar to those discussed in the paper. We present these analyses in the Online Appendix.

${ }^{7}$ As robustness tests, we performed a logit and a probit regression when LATER OR EXPANSION is the dependent variable. The inferences from these results are similar to those discussed in the paper. We present these analyses in the Online Appendix.
} 
Panel B of Table 3 reports the results when DENOMINATIONS is our measure of religiosity. Similarly, to the results for ADHERENTS, we find that DENOMINATIONS is positively associated with reduced $\mathrm{VC}$ risk taking, as shown by the positive and significant association between DENOMINATIONS and our three dependent variables. Specifically, DENOMINIATIONS is significantly associated with NUMBER OF ROUNDS (coeff: $0.101 \mathrm{t}-$ stat: 3.31) and NUMBER OF INVESTORS (coeff: 0.203 t-stat: 4.08) at the $1 \%$ level. DENOMINATIONS is significantly associated with LATER OR EXPANSION (coeff: $0.051 \mathrm{t}$ stat: 2.17$)$ at the $5 \%$ level. The economic effects of these results suggest that a 1 -standard deviation increase in DENOMINATIONS increases NUMBER OF ROUNDS by 0.029 and NUMBER OF INVESTORS by 0.057 . These increases correspond to approximately $5 \%$ of the standard deviation of NUMBER OF ROUNDS, and 6\% of NUMBER OF INVESTORS. Similarly, a 1-standard deviation increase in DENOMINATIONS increases the propensity of investing in the LATER OR EXPANSION phase by $2.8 \% .^{8}$

We find that the coefficients on the control variables are similar when either DENOMINATIONS or ADHERENTS is our measure of religiosity. VC experience and distance between the VC firm and company are associated with reduced VC risk taking, as shown by the significantly positive coefficient on $V C_{-} A G E$ and DISTANCE for all dependent variables. Moreover, when a company hails from a risky industry, such as information technology $\left(C \_I T\right)$ or medical (C_MEDICAL), it tends to engage in a larger number of financing rounds and to have a larger number of investors. Conversely, when a company has previously secured seed (SEED_STAGE) or early-stage (EARLY_STAGE) capital, and hence may be less risky, it tends to engage in a smaller number of financing rounds and to have fewer investors.

[Table 3 here]

\section{Robustness tests}

\footnotetext{
${ }^{8}$ The economic significance of our results is comparable to that of Gao et al. (2017).
} 


\subsection{Instrumental variable analysis}

Thus far, we have documented a significant and positive relation between local religious beliefs and reduced risk taking. While this relation is consistent with our conjecture that local religious beliefs lead to lower risk taking due to increased risk aversion, it nevertheless may be driven by endogeneity. For example, we may observe such a relationship due to reverse causality, i.e., if companies that are less risky tend to opt for investments from more religious VC. In order to mitigate this concern, we run an instrumental variable analysis.

We use three-year lagged religiosity measures as the instrument in the first stage for all regressions (Hilary and Hui, 2009). We also use total county population lagged by three years, except for the number of rounds specifications, where we use the lagged three-year proportion of white population in a VC county. Such variables are stable over time, so historical values are correlated with the current religiosity measure (the relevance criterion). However, we do not expect three-year lagged values to have any effect on current VC firm risk taking other that through current religiosity (exclusion criterion). The use of instruments with a three-year lag is motivated by Cumming and Johan (2013), who show that the investment cycle for a VC has an average duration of three years from initial investment to exit.

Table 4 presents the results from the second-stage regression. Panel A reports the estimated coefficients on the religiosity measures where the independent variable is NUMBER OF ROUNDS, panel B reports for NUMBER OF INVESTORS, and panel C for LATER OR EXPANSION. Consistent with our previous results, the second-stage regressions indicate that religiosity is associated with reduced $\mathrm{VC}$ risk taking, as shown by the positive and significant coefficients on the fitted values for religiosity when any of the risk taking variables are the dependent variables. The magnitudes of the estimated coefficients also remain similar to those in previous findings. The first-stage F-tests have p-values of 0.000 in all regressions, and the Hansen-Sargan J-statistic is insignificant in all specifications (p-values are between 0.1 and 
1.5), hence failing to reject the orthogonality condition. Taken together, these tests suggest that the instruments are adequate.

[Table 4 here]

\subsection{Including VC FEs}

Note that, in Eq. (1), we include county fixed effects to control for time-invariant county characteristics that may be correlated with religiosity, and year fixed effects to control for time trends in religiosity. However, the observed relation between religiosity and risk taking may be driven by cross-sectional variation in VC firms. Specifically, VC risk taking may be driven by VC firm characteristics other than religiosity, but which may be still correlated with religiosity. To address this possibility, we introduce VC firm fixed effects in Eq. (1).

Table 5 shows the results. Panel A reports the results with ADHERENTS as our measure of religiosity, and panel B with DENOMINATIONS as our measure of religiosity. When we use either ADHERENTS or DENOMINATIONS, we find a positive association between religiosity and our measures for risk taking. As expected, the magnitude of the coefficients is marginally smaller than for our main analysis, but the relation is statistically significant for most specifications. The relation between ADHERENTS and NUMBER OF INVESTORS (coeff.: 0.296 t-stat.: 1.67) is significant at the $10 \%$ level. Similarly, the relation between DENOMINATIONS and NUMBER OF ROUNDS (coeff.: 0.088 t-stat: 1.69) or NUMBER OF INVESTORS (coeff. :0.149 t-stat.:1.77) is significant at the $10 \%$ level. The relation between DENOMINATIONS and LATER OR EXPANSION (coeff. :0.119 t-stat.:2.94) is significant at the $1 \%$ level.

[Table 5 here]

\subsection{Falsification tests}

Given that our story relates to the effect of VC religiosity on VC risk taking, we must also examine the religiosity of the portfolio firms, the entrepreneurs in which a VC invests. We 
need to ensure that, in line with our predictions, it is the religiosity of the $\mathrm{VC}$ that drives the observed results, not the religiosity of the entrepreneur.

To test this notion, we conduct a falsification test, where we substitute the religiosity of the VC firm in Eq. (1) with the religiosity of the portfolio firm. Importantly, in this analysis, we also include VC firm fixed effects to control for time-invariant VC characteristics that may be related to its investments. In so doing, we are essentially examining the effect of variation in portfolio firm religiosity for a VC firm on that firm's level of risk taking. If the religiosity of the VC firm is driving our results, we expect to find no significant association between portfolio firm religiosity and VC risk taking.

Panels A and B of Table 6 show the results. In panel A, religiosity of the portfolio firm is captured by the number of adherents (PORTFOLIO COMPANY ADHERENTS); in panel B, religiosity of the investee firm is captured by denominations (PORTFOLIO COMPANY DENOMINATIONS). In both panels, the coefficient on portfolio company religiosity is negative but insignificant for all measures of VC risk taking. This result bolsters our story that the religiosity of the VC influences VC risk taking, not portfolio company religiosity.

Another possibility is that our main results may be driven by the ability of $\mathrm{VC}$ firms and entrepreneurs of similar religious denominations to communicate better and hence mitigate information asymmetries. In other words, it is possible that similarities in religiosity between the VC and the portfolio firm drive our results. If this alternative explanation holds, we would expect investments in portfolio firms located in the same county as the VC firms (i.e., where the portfolio and $\mathrm{VC}$ firms have similar religiosity levels) to be incrementally related to $\mathrm{VC}$ risk taking, versus investments in firms located in a different county.

To test this notion, we create an indicator variable, SAME COUNTY, that equals 1 if the $\mathrm{VC}$ and the portfolio firm are located in the same county, and 0 otherwise. Importantly we run this analysis including VC firm fixed effects, so we compare investments in portfolio firms 
located in the same county as the VC with those located in a different county for the same VC firm. If the alternative explanation drives VC risk taking, we should observe a statistically significant relation between SAME COUNTY and our measures for VC risk taking.

Panel $\mathrm{C}$ of Table 6 shows the results. For our three measures of risk taking, the coefficient on SAME COUNTY is insignificant, suggesting that the similarity in religiosity between the VC firm and the portfolio firm does not drive our results. It is pertinent to note that this result does not suggest information asymmetry does not affect VC decision making. In fact, the control for it in our main analysis, DISTANCE, is positive and significant in all of our specifications. This suggests that greater information asymmetry between the VC and portfolio firms is associated with an increased number of rounds and number of investors, as well as investments in the later or expansion stage. The insignificant result in panel $\mathrm{C}$ of Table 6 merely suggests that similarity in religion between the $\mathrm{VC}$ and the portfolio firm is not associated with $\mathrm{VC}$ risk taking. This result further strengthens our hypothesis that $\mathrm{VC}$ religiosity influences VC risk taking.

[Table 6 here]

\subsection{Other robustness tests}

We conduct additional tests to confirm the robustness of our results. For the sake of brevity, and to facilitate exposition, we discuss and present those results in greater detail in the Online Appendix.

First, we test whether our results are robust to different econometric choices. Given the discrete nature of the distribution of the NUMBER OF ROUNDS and NUMBER OF INVESTORS, we estimate Eq. (1) for these two measures of risk as a Poisson and a negative binomial (NB) model. In both regressions, we express the dependent variables in levels. Moreover, to ensure that our results are not driven by the transformation, we apply the inverse 
hyperbolic sine transformation (Bellemare and Wichman, 2019) to NUMBER OF ROUNDS and NUMBER OF INVESTORS, instead of using the natural log transformation.

Finally, to ensure that our result for LATER OR EXPANSION is not driven by the choice of econometric model, we test whether our results are robust if we estimate Eq. (1) as a probit or a logit regression. Results for these analyses are in Tables A-C of the Online Appendix. The inferences from these tests are in line with our main results, and suggest they are not sensitive to our econometric choices.

Second, we test whether our results are sensitive to the way we construct our religiosity measures. Following prior literature (e.g., Alesina and La Ferrara, 2000; Hilary and Hui, 2009; Dyreng et al., 2012; Adhikari and Agrawal, 2016a, 2016b; Gao et al., 2017), we use linear interpolation to fill religiosity data for years not covered by the ARDA decennial surveys. To ensure our results are not sensitive to interpolation, we run a robustness test where religiosity data for years with missing data is taken from the closest ARDA survey. The results are in Table D of the Online Appendix and are similar to our main results. They suggest our results are not sensitive to the way we calculate religiosity for years with missing data.

Third, we test for the possibility that the specific investment strategy used by the VC firm is correlated with religiosity, and hence may bias our results. To test this notion, we follow Shu et al. (2012) and Gao et al. (2017) and interact year and strategy fixed effects. We define strategy as investments in specific industries: 1) information technology; 2) medical, health, or life science; or 3) non-high technology. The results are in Table E of the Online Appendix and suggest that VC strategy does not influence our main results.

Fourth, to address the possibility that our results may be driven by VC activity clustered in a specific county, we re-run our main analysis, excluding each county one by one. We then use the coefficients on the remaining sample to plot coefficient distribution graphs. We report the graphs for each specification in Figure A of the Online Appendix. The coefficient 
distribution graphs are narrow, suggesting that the observed relation between VC religiosity and $\mathrm{VC}$ risk taking is not driven by specific counties.

Fifth, to mitigate the possibility that another omitted variable correlated with religiosity is driving our results, we examine how religiosity affects investments for the subsample of VC firms that changed counties during our sample period. Change in county represents a quasiexogenous shock to $\mathrm{VC}$ religiosity, because we do not expect VC firms to change the location of their headquarters simply because of differences in religiosity between two counties. If our prediction that $\mathrm{VC}$ religiosity is driving $\mathrm{VC}$ risk taking is correct, we expect a difference in religiosity between the two counties to be associated with our measures for VC risk taking.

To have a cleaner setting, for this analysis, we only consider VCs that moved once during our sample period. We also distinguish between firms that moved to a less from those that move to a more religious county. If $\mathrm{VC}$ religiosity is driving our results, we expect an increase in risk aversion for firms that moved to a more religious county when compared to those VC firms that moved to a less religious county.

The results are in Table F of the Online Appendix. We find that, after relocation, VCs that moved to a more religious county are more likely to be involved in staging and syndication than those that moved to a less religious county. Taken together, these results suggest that, in line with our prediction, relocating to a more religious county results in more risk-averse VC investments.

\section{Further analysis}

In this section, we briefly discuss the motivation for further analyses of when the relation between religiosity and VC risk taking behavior is stronger. Similarly, to section 5.4., for the sake of brevity and to facilitate exposition, we discuss these analyses and their results in greater detail in the Online Appendix. 
First, we test whether the effect of VC religiosity on VC risk taking is stronger when asymmetric information and the subsequent agency conflict is expected to be most pervasive. Specifically, we expect investments in information technology firms to signal high investment risk and high agency conflict. These firms typically 1) consist of the entrepreneur and a few key individuals with limited business experience, 2) have limited tangible assets, and 3) place an overly high value on the entrepreneur's human capital. To test whether the effect of VC religiosity on VC risk taking is stronger under these conditions, we interact our measures of religiosity with $C_{-} I T$, an indicator variable that equals 1 if the investee firm operates in the information technology sector, and 0 otherwise.

Table $\mathrm{G}$ of the Online Appendix reports the results. We find that the effect of religiosity on $\mathrm{VC}$ risk taking is stronger in the presence of greater information asymmetry and agency conflict. For both measures of religiosity, we find that the interaction term between religiosity and $C_{-} I T$ is positive and significant. These results confirm our prediction that, when VC firms invest in riskier industries, the effect of religiosity on VC investments is stronger.

Second, we examine whether the previously observed relation between religiosity and $\mathrm{VC}$ risk taking is sensitive to the specific religious denomination to which people adhere. The extant literature has found mixed evidence on the relation between specific religious denominations and risk taking. Barsky et al. (1997), Stulz and Williamson (2003), and Benjamin et al. (2016) find that Catholics tend to be more risk tolerant than Protestants, while Renneboog and Spaenjers (2012) and Baxamusa and Jalal (2016) find that Catholics tend to be more risk averse than Protestants. Given this inconclusive evidence, we examine whether the prevalent denomination in the county in which the $\mathrm{VC}$ is located influences $\mathrm{VC}$ risk taking. We substitute RELIGIOSITY in Eq. (1) with a new variable, PROTESTANTS TO CATHOLICS, which captures the relative number of Protestants to Catholics in the county in which the VC is located. 
Table $\mathrm{H}$ of the Online Appendix presents the results. For the three measures of VC risk taking, we find that the coefficient on PROTESTANTS TO CATHOLICS is positive, albeit only significant for NUMBER OF ROUNDS and NUMBER OF INVESTORS. These results are consistent with Barsky et al. (1997), Stulz and Williamson (2003), and Benjamin et al., (2016). They and provide evidence that VCs located in counties with more Protestants than Catholics tend to be more risk averse in their investment decisions.

\section{Conclusion}

The lack of literature on how religiosity influences VC investment decision making is surprising, given that prior literature has shown it strongly influences corporate (Hilary and Hui, 2009) and mutual fund (Shu et al., 2012) investment decisions. However, VCs differ in that they are high risk investors exposed to significant investment risk. They are only lightly regulated and are allowed to seek capital from professional investors. It is therefore ex ante unclear what effect (if any) religiosity has on VC decision making.

To the best of our knowledge, this is the first study to provide evidence about the relation between religiosity and $\mathrm{VC}$ investment decision making. Our results are consistent with the notion that religiosity is positively related to risk aversion, and, hence, VC firms located in more religious areas are more likely to be involved in staging, syndication, and investing in startups at a later stage. In further analyses, we find that the influence of religiosity on VC investments is stronger with greater agency costs, and with a greater adherence to Protestantism than to Catholicism.

As with any other research, interpretation of our findings is subject to several caveats. First, since we cannot directly observe risk taking, we rely on measures that prior literature has shown are correlated with the magnitude of VC risk taking. Nevertheless, it is likely that these measures capture risk taking with errors. Second, the religiosity of the VC partners is unobservable. Therefore, we proxy for organizational religiosity using measures of religiosity 
of the geographic area in which the organization operates. While various theoretical and empirical studies have provided support for such a proxy, it is likely that we capture VC religiosity with error. 


\section{Appendix}

\section{Table AI}

Variable Descriptions

\begin{tabular}{ll}
\hline Name & Definition [Source] \\
\hline Dependent variables & \\
NUMBER OF ROUNDS & $\begin{array}{l}\text { Natural logarithm of 1 plus the number of rounds of financing provided } \\
\text { to the company by VCs [VentureXpert, Thomson Financial] } \\
\text { Natural logarithm of 1 plus the number of investors in the company } \\
\text { [VentureXpert, Thomson Financial] } \\
\text { Indicator variable that equals 1 if the first funding was at the later or } \\
\text { expansion stage of company development [VentureXpert, Thomson } \\
\text { Financial] }\end{array}$ \\
\hline
\end{tabular}

Religiosity variables

ADHERENTS

DENOMINATIONS

ADHERENTS_CLOSE

DENOMINATIONS_CLOSE

PROTESTANTS TO

CATHOLICS

Deal-level variables

INDEPENDENT VC

VC AGE

C_IT

C_MEDICAL

SEED_STAGE

EARLY_STAGE

STRATEGY
Total number of adherents to any recognized religious denomination, scaled by total population for the county. Data come from the ARDA decennial surveys. Observations for missing years are computed using interpolation [ARDA]

Total number of recognized religious denominations in a county per 1,000 people in the county. Data come from the ARDA decennial surveys. Observations for missing years are computed using interpolation [ARDA] Total adherents to any recognized religious denomination, scaled by total population for the county. Data come from the ARDA decennial surveys. Observations for missing years are deemed to be the same as those for the closest ARDA survey [ARDA]

Total number of recognized religious denominations in a county per 1,000 people in the county. Data come from the ARDA decennial surveys. Observations for missing years are deemed to be the same as those for the closest ARDA survey [ARDA]

Number of adherents to the largest Protestant religious denominations, scaled by the sum of the number of adherents to the Roman Catholic religion and the number of adherents to the largest Protestant religious denominations. Data come from the ARDA decennial surveys. Observations for missing years are computed using interpolation [ARDA]

Indicator variable that equals 1 if the $\mathrm{VC}$ is an independent private equity firm, and 0 otherwise [VentureXpert, Thomson Financial]

Natural logarithm of 1 plus age of the VC firm [VentureXpert, Thomson Financial]

Indicator variable that equals 1 if the company industry is information technology, and 0 otherwise [VentureXpert, Thomson Financial]

Indicator variable that equals 1 if the company industry is medical, health, or life science, and 0 otherwise [VentureXpert, Thomson Financial]

Indicator variable that equals 1 if the company raised seed finance, and 0 otherwise [VentureXpert, Thomson Financial]

Indicator variable that equals 1 if the company raised early-stage finance, and 0 otherwise [VentureXpert, Thomson Financial]

Indicator variable that equals 1 if the $\mathrm{VC}$ firm has investments in specific industries: 1) information technology; 2) medical, health, or life science; or 3) non-high technology, and 0 otherwise [VentureXpert, Thomson Financial]

County-level variables

DISTANCE

Natural logarithm of 1 plus distance in miles between the VC firm and company. The data come from http://www.nber.org/data/county-distancedatabase.html 
F_POP/C_POP

F_POP_AGE/C_POP_AGE

F_EMP/C_EMP

F_INC.C_INC

F_GRP/C_GRP

F_EDU/C_EDU

F_FM/C_FM

F_DENSITY/C_DENSITY

F_HOUSE_INC/C_HOUSE_INC
Firm (F) or company (C) natural logarithm of total population in a county: WP001 [Woods \& Poole Economics]

Firm (F) or company $(\mathrm{C})$ natural logarithm of median population age in a county: WP020 [Woods \& Poole Economics]

Firm (F) or company (C) natural logarithm of total employment in a county: WP032 [Woods \& Poole Economics]

Firm (F) or company (C) natural logarithm of total personal income per capita (2009 \$) in a county: WP089 [Woods \& Poole Economics]

Firm (F) or company (C) natural logarithm gross regional product in a county: WP092 [Woods \& Poole Economics]

Firm (F) or company $(\mathrm{C})$ natural logarithm of educational attainment in a county [United States Department of Agriculture, Economic Research Service]

Firm $(\mathrm{F})$ or company $(\mathrm{C})$ ratio of male to female population in a county: WP030/WP031 [Woods \& Poole Economics]

Firm (F) or company (C) persons per household in a county: WP093 [Woods \& Poole Economics]

Firm (F) or company (C) natural logarithm of mean household income (2009 \$) in a county: WP095 [Woods \& Poole Economics] 


\section{References}

Adhikari, B., Agrawal, A., 2016a. Religion, gambling attitudes and corporate innovation. J. Corp. Financ. 37, 229-248.

Adhikari, B., Agrawal, A., 2016b. Does Local Religiosity Matter for Bank Risk-Taking? J. Corp. Financ. 38, 272-293.

Admati, A., Pfleiderer, P., 1994. Robust financial contracting and the role of venture capitalists. J. Financ. 49, 371-402.

Alesina, A., La Ferrara, E., 2000. Participation in heterogeneous communities. Q. J. Econ. 115, 847-904.

Andrieu, G., Groh, A.P., 2018. Specialist versus generalist investors: Trading off support quality, investment horizon and control rights. Euro. Econ. Rev. 101, 459-478.

Audretsch, D.B, Bönte, W., Tamvada, J.P., 2013. Religion, social class, and entrepreneurial choice. J. Bus. Ventur. 28 (6), 774-789.

Barsky, R.B., Juster, F.T., Kimball, M.S., Shapiro, M.D., 1997. Preference parameters and behavioural heterogeneity: an experimental approach in the Health and Retirement Study. Q. J. Econ. 112, 537-579.

Baxamusa, M., Jalal, A., 2016. CEO's religious affiliation and managerial conservatism. Financ. Manag. 67-104.

Bellemare, M.F., Wichman, C.J., 2019. Elasticities and the inverse hyperbolic sine transformation. Oxford Bull. of Econ. and Stat.

Benjamin, D.J., Choi, J.J., Fisher, G., 2016. Religious identity and economic behavior. Rev. Econ. Stat. 98, 617-637

Berger, A., Frame, W., 2007. Small business credit scoring and credit availability. J. Sm. Bus. Manag. 45, 5-22.

Berger, A., Udell, G., 1998. The economics of small business finance: The roles of private equity and debt markets in the financial growth cycle. J. Bank. Financ. 22, 613-673.

Berger, A., Udell, G., 2006. A more complete conceptual framework for SME finance. J. Bank. Financ. 30, 2945-2966.

Berglof, E., 1994. A Control Theory of Venture Capital Finance. J. Law, Econ., Org. 10, 247267.

Bertoni, F., Croce, A., Guerini, M., 2015. Venture capital and the investment curve of young high-tech companies. J. Corp. Financ. 35 159-176.

Bertoni, F., Groh, A.P., 2014. Mode of exit and cross-border VC investments. Corporate Governance: An International Review 22, 84-99. 
Bienz, C., Walz, U., 2010. Venture capital exit rights. J. Econ. Manag. Strateg. 19, 1071-1116.

Boone, J.P., Khurana, I.K., Raman, K.K., 2012. Religiosity and tax avoidance. J. Amer. Tax. Assoc. 35, 53-84.

Bottazzi, L., Da Rin, M., Hellmann, T., 2016. The importance of trust for investment: Evidence from venture capital. Rev. Financ. Stud. 29, 2283-2318.

Casamatta, C., 2003. Financing and advising: Optimal financial contracts with venture capitalists. J. Financ. 58, 2059-2086.

Casamatta, C., Haritchabalet, C., 2007. Experience, screening and syndication in venture capital investments. J. Financ. Inter. 16, 368-398.

Chircop, J., Fabrizi, M., Ipino, E., Parbonetti, A., 2017. Does branch religiosity influence bank risk-taking? J. Bus. Financ. Account. 44, 271-294.

Chuah, S.H, Gächter, S., Hoffmann, R., Tan, J.H.W., 2016. Religion, discrimination and trust across three cultures. Euro. Econ. Rev. 90, 280-301.

Cialdini, R.B., Goldstein, N.J., 2004. Social influence: Compliance and conformity. Ann. Rev. Psych. 55, 591-621.

Cumming, D., Johan, S.A., 2006. Is it the Law or the Lawyers? Investment Covenants around the World. Euro. Financ. Manag. 12, 535-574.

Cumming, D., Johan, S.A., 2008. Preplanned exit strategies in venture capital. Euro. Econ. Rev. 52, 1209-1241.

Cumming, D., Johan, S.A., 2013. Venture Capital and Private Equity Contracting: An International Perspective, Elsevier Science Academic Press.

Dohmen, T., Falk, A., Huffman, D., Sunde, U., Schupp, J., Wagner, G.G., 2011. Individual risk attitudes: measurement, determinants and behavioral consequences. J. Euro. Econ. Assoc. 9, $522-550$.

Dowling, J., Pfeffer, K., 1975. Organizational legitimacy: Special values and organizational behavior. Pacific Sociological Review, 18, 122-136.

Duffner, S., Schmid, M. M., Zimmermann, H., 2009. Trust and success in venture capital financing-An empirical analysis with German survey data. KYKLOS, 62(1), 15-43.

Dyreng, S.D., Mayew, W.J., Williams, C.D., 2012. Religious social norms and corporate financial reporting. J. Bus. Financ. Account. 39, 845-875.

Espenlaub, S., Khurshed, A., Mohamed, A., 2015. Venture capital exits in domestic and crossborder investments. J. Bank. Financ. 53, 215-232. 
Ewens, M., Rhodes-Kropf, M., 2015. Is a VC partnership greater than the sum of its parts? J. Financ. 70, 1081-1113.

Freel, M., 1999. The financing of small firm product innovation within the UK. Technovation 19, 707-719.

Freel, M., 2000. Barriers to product innovation in small manufacturing firms. International Small Business Journal, 18, 60-80.

Freel, M., 2007. Are small innovators credit rationed? Small Business Economics 28, 23-35.

Gao, L., Wang, Y., Zhao, J., 2017. Local religious beliefs and hedge fund risk-taking behaviors. J. Corp. Financ. 47, 1-22

Gasper, K., Clore, G.L., 1998. The persistent use of negative affect by anxious individuals to estimate risk. J. Pers. Soc. Psych. 5, 1350-1363.

Giot, P., Schwienbacher, A., 2007. IPOs, trade sales and liquidations: Modelling venture capital exits using survival analysis. J. Bank. Financ. 31, 679-702.

Gompers, P., 1995. Optimal investment, monitoring, and the staging of venture capital. J. Financ. 50, 1461-1489.

Gompers, P., Lerner, J., 1999. Conflict of interest in the issuance of public securities: Evidence from venture capital. J. Law. Econ. 42, 1-28.

Gorman, M., Sahlman, W.A., 1989. What do venture capitalists do? J. Bus. Ventur. 4, 231248.

Groh, A.P., von Liechtenstein, H., 2011. The first step of the capital flow from institutions to entrepreneurs: The criteria for sorting venture capital funds. Euro. Financ. Manag. 17, 532559.

Groh, A.P., von Liechtenstein, H., Lieser, K., 2010. The European venture capital and private equity country attractiveness indices. J. Corp. Financ. 16, 205-224.

Grullon, G., Kanatas, G., Weston, J., 2009. Religion and corporate (mis)behavior, Working paper. Rice University.

Hain, D., Johan, S., Wang, D., 2016. Determinants of cross-border venture capital investments in emerging and developed economies: the effects of relational and institutional trust. J. Bus. Ethics 138, 743-764.

Hilary, G., Hui K.W., 2009. Does religion matter in corporate decision-making in America? J. Financ. Econ. 93, 455-473.

Hirsch, J., Walz, U., 2011. Financing decisions along a firm's life-cycle: Debt as a commitment device. Euro. Financ. Manag. 17, 898-927. 
Hogg, A., Abrams, D., 1988. Social identifications: A social psychology of intergroup relations and group processes. Routledge.

Iannaccone, L., 1998. Introduction to the economics of religion. J. Econ. Literat. 36, 14651496.

Jia, N., Wang, D., 2017. Skin in the game: General partner capital commitment, investment behavior and venture capital fund performance, J. Corp. Financ. 47, 110-130.

Kaplan, S., Schoar, A., 2005. Private Equity Performance: Returns, Persistence, and Capital Flows. J. Financ. 60, 1791-823.

Kaplan, S., Strömberg, P., 2003. Financial contracting theory meets the real world: An empirical analysis of venture capital contracts. Rev. Econ. Stud. 70, 281-315.

Kaplan, S., Strömberg, P., 2004. Characteristics, contracts, and actions: Evidence from venture capitalist analyses. J. Financ. 59, 2177-2210.

Knight, F.H. 1921. Risk, uncertainty and profit. Chicago: University of Chicago Press.

Kohlberg, L., 1984. Essays on Moral Development Vol. 2, the Psychology of Moral Development. San Francisco, CA: Harper \& Row.

Kumar, A., Page J.K., Spalt, O.G., 2011. Religious beliefs, gambling attitudes, and financial market outcomes. J. Financ. Econ. 102, 671-708.

Lehrer, E.L., 2004. The role of religion in union formation: An economic perspective. Population Research and Policy Review 23, 161-185.

Lim, C., 2013. Counting the faithful: Measuring local religious contexts in the United States.

J. Scient. Stud. Relig. 52, 386-400

Liu, E.Y., 2010. Are risk-taking persons less religious? Risk preference, religious affiliation, and religious participation in Taiwan. J. Scient. Stud. Relig. 49, 172-178.

Malinowski, B., 1925. Magic, Science, and Religion. New York: Doubleday.

Manigart, S., De Waele, K., Wright, M., Robbie, K., Desbrières, P., Sapienza, H.J., Beekman, A., 2002. Determinants of required return in venture capital investments: a five-country study. J. Bus. Ventur. 17, 291-312.

Manigart, S., Lockett, A., Meuleman, M., Wright, M. Landström, H., Bruining, H., Desbrieres, P., Hommel, U., 2006. Venture capitalists' decision to syndicate. Entrepreneurship Theory and Practice 30, 131-153.

McGuire, S.T., Omer, T.C., Sharp, N.Y., 2011. The impact of religion on financial reporting irregularities. Account. Rev. 87, 645-673.

Miller, A.S., Hoffmann, J.P., 1995. Risk and religion: an explanation of gender differences in religiosity. J. Scient. Stud. Relig. 34, 63-75. 
Mohamed, A. Schwienbacher, A., 2016. Voluntary disclosure of corporate venture capital investments, J. Bank. Financ. 68, 69-83.

Nahata, R., 2008. Venture capital reputation and investment performance. J. Financ. Econ. 90, 127-151.

National Venture Capital Association, 2012. National Venture Capital Association 2012 Yearbook: Virginia.

Neus, W., Walz, U., 2005. Exit timing of venture capitalists in the course of an initial public offering. J. Financ. Interm. 14, 253-277. Noussair, N. C., Trautmann, T.S., van de Kuilen, G., Vellekoop, N., 2013. Risk aversion and religion. J. Risk Uncert. 47, 165-183

Olson, D.V.A., Perl, P., 2011. A friend in creed: Does the religious composition of geographic areas affect the religious composition of a person's close friends? J. Scien. Stud. Relig. 50, 483-502.

PitchBook-NVCA Venture Monitor, 2016. National Venture Capital Association and PitchBook 2016 report.

Renneboog, L., Spaenjers, C., 2012. Religion economic attitude and household finance. Oxford Economic Papers 64, 103-127.

Rokeach, M., 1968. Beliefs, attitudes and values, San Francisco: Jossey-Bass Inc.

Sahlman, W.A., 1990. The structure and governance of venture-capital organizations. J. Financ. Econ. 27, 473-521.

Sahlman, W., 2010. Risk and reward in venture capital. Harvard Business School Note 811036, 1-37.

Sapienza, H.J., Manigart, S., Vermeir, W., 1996. Venture capitalist governance and value added in four countries. J. Bus. Venturing 11, 439-469.

Schmidt, K., 2003. Convertible securities and venture capital finance. J. Financ. 58, 11391166.

Schneider, B., 1987. The people make the place. Personnel Psychology 40, 437-453.

Shu, T., Sulaeman, J., Yeung, P.E., 2012. Local religious beliefs and mutual fund risk-taking behaviors, Manag. Sci. 58, 1779-1796.

Stulz, R., Williamson, R., 2003. Culture, openness and finance. J. Financ. Econ. 70, 313-349.

Sunstein, C.R., 1996. Social norms and social rules. Columbia Law Review 96, 903-968.

Tajfel, H., 1978. Differentiation between social groups: Studies in the social psychology of intergroup relations. Academic Press. 
Tian, X., 2011. The causes and consequences of venture capital stage financing. J. Financ. Econ. 101, 132-159.

Ueda, M., 2004. Banks versus Venture Capital: Project Evaluation, Screening, and Expropriation. J. Financ. 59, 601-621.

Wang, S., Zhou, H., 2004. Staged financing in venture capital: moral hazard and risks, J. Corp. Financ. 10, 131-155.

Wright, M., Lockett, A., 2003. The structure and management of alliances: Syndication in the venture capital industry. J. Manag. Stud. 40, 2073-2102. 
Table 1

Sample Distribution

This table shows sample distributions by year for the variables used in our base model. The sample includes all round-by-round VC investments in portfolio firms from 1980 through 2014. The sample size consists of 91,020 observations. Column (2) shows the number of observations; column (3) shows the total invested in thousands by the VC firm in a portfolio company; column (4) shows the number of VC investors in the portfolio company; column (5) shows the number of financing rounds; and column (6) shows the percentage of rounds in each year that involve VC syndicates. All values are in levels.

\begin{tabular}{|c|c|c|c|c|c|}
\hline YEAR & $\mathrm{N}$ & $\begin{array}{l}\text { TOTAL } \\
\text { INVESTED } \\
(\$ 000)\end{array}$ & $\begin{array}{l}\text { NUMBER OF } \\
\text { INVESTORS } \\
\text { (levels) }\end{array}$ & $\begin{array}{c}\text { NUMBER OF } \\
\text { ROUNDS } \\
\text { (levels) }\end{array}$ & $\begin{array}{c}\text { PERCENTAGE } \\
\text { OF ROUNDS } \\
\text { THAT ARE } \\
\text { SYNDICATED }\end{array}$ \\
\hline 1980 & 394 & 19,735 & 23 & 5 & $85 \%$ \\
\hline 1981 & 659 & 15,832 & 27 & 6 & $88 \%$ \\
\hline 1982 & 995 & 17,689 & 29 & 6 & $87 \%$ \\
\hline 1983 & 1,536 & 22,545 & 33 & 6 & $91 \%$ \\
\hline 1984 & 1,748 & 20,949 & 34 & 6 & $92 \%$ \\
\hline 1985 & 1,460 & 19,805 & 34 & 7 & $91 \%$ \\
\hline 1986 & 1,751 & 27,664 & 39 & 7 & $91 \%$ \\
\hline 1987 & 1,695 & 27,661 & 34 & 7 & $88 \%$ \\
\hline 1988 & 1,618 & 28,837 & 34 & 7 & $89 \%$ \\
\hline 1989 & 1,578 & 33,323 & 33 & 7 & $88 \%$ \\
\hline 1990 & 1,224 & 26,923 & 30 & 8 & $80 \%$ \\
\hline 1991 & 1,077 & 29,699 & 30 & 8 & $79 \%$ \\
\hline 1992 & 1,380 & 31,328 & 28 & 8 & $80 \%$ \\
\hline 1993 & 1,040 & 31,354 & 28 & 8 & $78 \%$ \\
\hline 1994 & 1,181 & 38,897 & 27 & 7 & $81 \%$ \\
\hline 1995 & 1,530 & 36,342 & 22 & 6 & $75 \%$ \\
\hline 1996 & 2,011 & 40,878 & 21 & 6 & $77 \%$ \\
\hline 1997 & 2,737 & 43,565 & 22 & 6 & $82 \%$ \\
\hline 1998 & 2,967 & 50,440 & 21 & 6 & $80 \%$ \\
\hline 1999 & 5,009 & 60,456 & 21 & 5 & $86 \%$ \\
\hline 2000 & 7,029 & 55,097 & 19 & 5 & $88 \%$ \\
\hline 2001 & 4,059 & 56,612 & 22 & 6 & $85 \%$ \\
\hline 2002 & 3,118 & 58,075 & 25 & 7 & $86 \%$ \\
\hline 2003 & 3,235 & 62,507 & 26 & 7 & $86 \%$ \\
\hline 2004 & 3,707 & 59,341 & 26 & 7 & $89 \%$ \\
\hline 2005 & 3,853 & 58,263 & 25 & 7 & $88 \%$ \\
\hline 2006 & 4,510 & 60,287 & 23 & 6 & $86 \%$ \\
\hline 2007 & 5,020 & 55,633 & 22 & 6 & $86 \%$ \\
\hline 2008 & 5,055 & 50,279 & 20 & 6 & $83 \%$ \\
\hline 2009 & 3,592 & 56,102 & 20 & 6 & $79 \%$ \\
\hline 2010 & 4,350 & 49,981 & 16 & 5 & $82 \%$ \\
\hline 2011 & 4,432 & 47,990 & 14 & 4 & $84 \%$ \\
\hline 2012 & 1,609 & 57,654 & 13 & 4 & $72 \%$ \\
\hline 2013 & 1,813 & 48,303 & 13 & 4 & $75 \%$ \\
\hline 2014 & 2,048 & 49,043 & 12 & 4 & $75 \%$ \\
\hline Average & 2,601 & 41,403 & 25 & 6 & $84 \%$ \\
\hline
\end{tabular}


Table 2

Summary Statistics

This table shows summary statistics for the variables used in our base model. The sample includes all round-by-round VC investments in portfolio firms from 1980 through 2014. The sample size consists of 91,020 observations. All variables are as defined in Appendix Table AI.

\begin{tabular}{|c|c|c|c|c|c|c|c|}
\hline & Mean & S.D. & Min & $\mathrm{P} 25$ & Median & $\mathrm{P} 75$ & Max \\
\hline NUMBER OF ROUNDS & 1.80 & 0.54 & 0.69 & 1.39 & 1.79 & 2.20 & 2.89 \\
\hline NUMBER OF INVESTORS & 2.83 & 0.88 & 0.69 & 2.30 & 2.94 & 3.47 & 4.52 \\
\hline LATER OR_EXPANSION & 0.56 & 0.50 & 0.00 & 0.00 & 1.00 & 1.00 & 1.00 \\
\hline ADHERENTS & 0.48 & 0.10 & 0.31 & 0.42 & 0.44 & 0.56 & 0.74 \\
\hline DENOMINATIONS & 0.57 & 0.28 & 0.35 & 0.43 & 0.49 & 0.60 & 2.37 \\
\hline PROTESTANTS TO CATHOLICS & 0.14 & 0.17 & 0.04 & 0.05 & 0.08 & 0.12 & 0.89 \\
\hline VC_INDEPENDENT & 0.83 & 0.37 & 0.00 & 1.00 & 1.00 & 1.00 & 1.00 \\
\hline VC_AGE & 3.33 & 0.43 & 2.08 & 3.04 & 3.40 & 3.64 & 4.06 \\
\hline C_IT & 0.70 & 0.46 & 0.00 & 0.00 & 1.00 & 1.00 & 1.00 \\
\hline C_MEDICAL & 0.19 & 0.39 & 0.00 & 0.00 & 0.00 & 0.00 & 1.00 \\
\hline SEED_STAGE & 0.11 & 0.32 & 0.00 & 0.00 & 0.00 & 0.00 & 1.00 \\
\hline EARLY_STAGE & 0.26 & 0.44 & 0.00 & 0.00 & 0.00 & 1.00 & 1.00 \\
\hline DISTANCE & 2.69 & 2.12 & 0.00 & 0.00 & 3.49 & 4.06 & 6.48 \\
\hline F_POP & 6.86 & 0.93 & 2.84 & 6.54 & 6.65 & 7.37 & 9.19 \\
\hline C_POP & 7.08 & 0.75 & 4.76 & 6.60 & 7.26 & 7.42 & 9.19 \\
\hline F_POP_AGE & 3.57 & 0.08 & 3.38 & 3.51 & 3.57 & 3.63 & 3.73 \\
\hline C_POP_AGE & 3.55 & 0.08 & 3.37 & 3.50 & 3.56 & 3.61 & 3.72 \\
\hline F_EMP & 6.51 & 0.99 & 2.04 & 6.14 & 6.52 & 7.02 & 8.62 \\
\hline C_EMP & 6.71 & 0.79 & 4.16 & 6.21 & 6.82 & 7.06 & 8.64 \\
\hline F_INC & 10.84 & 0.32 & 10.10 & 10.61 & 10.86 & 11.10 & 11.75 \\
\hline C_INC & 10.81 & 0.32 & 10.16 & 10.57 & 10.79 & 11.02 & 11.76 \\
\hline F_GRP & 11.12 & 1.12 & 6.04 & 10.78 & 11.11 & 11.76 & 13.20 \\
\hline C_GRP & 11.31 & 0.93 & 8.25 & 10.91 & 11.41 & 11.91 & 13.20 \\
\hline F_EDU & 15.91 & 5.39 & 6.10 & 12.46 & 14.95 & 18.02 & 30.68 \\
\hline C_EDU & 15.66 & 4.93 & 6.00 & 12.52 & 15.24 & 18.25 & 30.10 \\
\hline F_FM & 1.03 & 0.04 & 0.96 & 0.99 & 1.03 & 1.05 & 1.13 \\
\hline C_FM & 1.02 & 0.04 & 0.96 & 0.99 & 1.02 & 1.05 & 1.13 \\
\hline F_DENSITY & 2.59 & 0.24 & 1.98 & 2.40 & 2.66 & 2.75 & 2.98 \\
\hline C_DENSITY & 2.62 & 0.24 & 1.98 & 2.44 & 2.68 & 2.83 & 2.99 \\
\hline F_HOUSE_INC & 11.79 & 0.33 & 11.02 & 11.56 & 11.80 & 12.06 & 12.44 \\
\hline C_HOUSE_INC & 11.77 & 0.30 & 11.14 & 11.55 & 11.76 & 11.99 & 12.45 \\
\hline
\end{tabular}


Table 3

Religiosity and VC Investment Characteristics

This table presents OLS regression analyses of religiosity on the number of rounds in column (1), the number of investors in column (2), and on the stage of company development in column (3). Panel A measures religiosity using ADHERENTS, and Panel B using DENOMINATIONS. All regressions include constant, deal, and company county characteristics and year fixed effects. Standard errors are clustered by VC firm. The sample includes all round-by-round VC investments in portfolio firms from 1980 through 2014. The sample size consists of 91,020 observations. All variables are as defined in Appendix Table AI. ***,**, and * denote 1\%, 5\%, and 10\% significance levels, respectively.

Panel A. ADHERENTS

\begin{tabular}{|c|c|c|c|c|c|c|}
\hline \multirow[t]{2}{*}{ 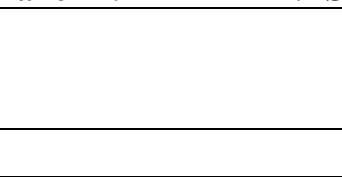 } & \multicolumn{2}{|c|}{$\begin{array}{c}(1) \\
\text { NUMBER OF } \\
\text { ROUNDS } \\
\end{array}$} & \multicolumn{2}{|c|}{$\begin{array}{c}(2) \\
\text { NUMBER OF } \\
\text { INVESTORS } \\
\end{array}$} & \multicolumn{2}{|c|}{$\begin{array}{c}(3) \\
\text { LATER OR } \\
\text { EXPANSION }\end{array}$} \\
\hline & Coeff. & t-Stat & Coeff. & t-Stat & Coeff. & t-Stat \\
\hline ADHERENTS & 0.133* & $(1.74)$ & $0.210^{*}$ & $(1.65)$ & $0.133 * *$ & (2.30) \\
\hline VC_INDEPENDENT & $0.053 * * *$ & (4.99) & $0.046 * *$ & $(2.41)$ & $-0.023 * *$ & $(-2.24)$ \\
\hline VC_AGE & $0.088 * * *$ & $(6.61)$ & $0.104 * * *$ & $(5.55)$ & $0.050 * * *$ & (4.89) \\
\hline C_IT & $0.111 * * *$ & $(9.61)$ & $0.281 * * *$ & $(16.31)$ & $0.027 * * *$ & $(3.51)$ \\
\hline C_MEDICAL & $0.248 * * *$ & (18.67) & $0.521 * * *$ & $(25.53)$ & $-0.070 * * *$ & $(-7.74)$ \\
\hline SEED_STAGE & $-0.311 * * *$ & $(-35.96)$ & $-0.497 * * *$ & $(-37.25)$ & & \\
\hline EARLY_STAGE & $-0.258 * * *$ & $(-46.92)$ & $-0.400 * * *$ & $(-48.50)$ & & \\
\hline DISTANCE & $0.016 * * *$ & (3.62) & $0.034 * * *$ & $(5.24)$ & $0.016 * * *$ & $(4.90)$ \\
\hline F_POP & -0.051 & $(-0.92)$ & 0.020 & $(0.20)$ & -0.072 & $(-1.61)$ \\
\hline C_POP & 0.078 & $(0.70)$ & $-0.344 *$ & $(-1.79)$ & 0.080 & $(0.82)$ \\
\hline F_POP_AGE & 0.073 & $(0.58)$ & 0.172 & $(0.82)$ & -0.015 & $(-0.14)$ \\
\hline C_POP_AGE & $-0.577 * *$ & $(-2.18)$ & $-2.046 * * *$ & $(-4.90)$ & -0.012 & $(-0.06)$ \\
\hline F_EMP & -0.021 & $(-0.23)$ & -0.197 & $(-1.29)$ & 0.039 & $(0.51)$ \\
\hline C_EMP & 0.151 & $(1.53)$ & $0.697 * * *$ & $(4.23)$ & -0.014 & $(-0.15)$ \\
\hline F_INC & 0.316 & $(0.91)$ & $1.009 *$ & (1.73) & 0.107 & $(0.44)$ \\
\hline C_INC & -0.375 & $(-0.75)$ & -0.304 & $(-0.44)$ & -0.099 & $(-0.27)$ \\
\hline F_GRP & 0.059 & $(1.13)$ & $0.151 *$ & $(1.83)$ & 0.014 & $(0.30)$ \\
\hline C_GRP & $-0.174 * *$ & $(-2.26)$ & $-0.391 * * *$ & $(-3.27)$ & 0.054 & $(0.86)$ \\
\hline F_EDU & -0.002 & $(-1.25)$ & -0.002 & $(-0.77)$ & $0.003 * *$ & (2.07) \\
\hline C_EDU & -0.005 & $(-1.62)$ & $-0.013 * *$ & $(-2.40)$ & -0.002 & $(-0.63)$ \\
\hline F_FM & -0.004 & $(-0.02)$ & $-0.924 * * *$ & $(-2.81)$ & $-0.531 * * *$ & $(-3.51)$ \\
\hline C_FM & 0.065 & $(0.14)$ & 0.297 & $(0.39)$ & $1.024 * * *$ & $(2.62)$ \\
\hline F_DENSITY & 0.182 & $(1.32)$ & $0.409 *$ & $(1.76)$ & 0.097 & $(0.99)$ \\
\hline C_DENSITY & $-0.412 * *$ & $(-1.99)$ & $-0.648 * *$ & $(-2.17)$ & -0.025 & $(-0.16)$ \\
\hline F_HOUSE_INC & -0.403 & $(-1.14)$ & $-1.022 *$ & $(-1.73)$ & -0.120 & $(-0.49)$ \\
\hline C_HOUSE_INC & 0.273 & $(0.55)$ & 0.181 & $(0.26)$ & 0.088 & $(0.25)$ \\
\hline COUNTY FE & Yes & & Yes & & Yes & \\
\hline YEAR FE & Yes & & Yes & & Yes & \\
\hline R-SQ & 0.234 & & 0.289 & & 0.068 & \\
\hline
\end{tabular}


Table 3 (continued)

Religiosity and VC Investment Characteristics

Panel B. DENOMINATIONS

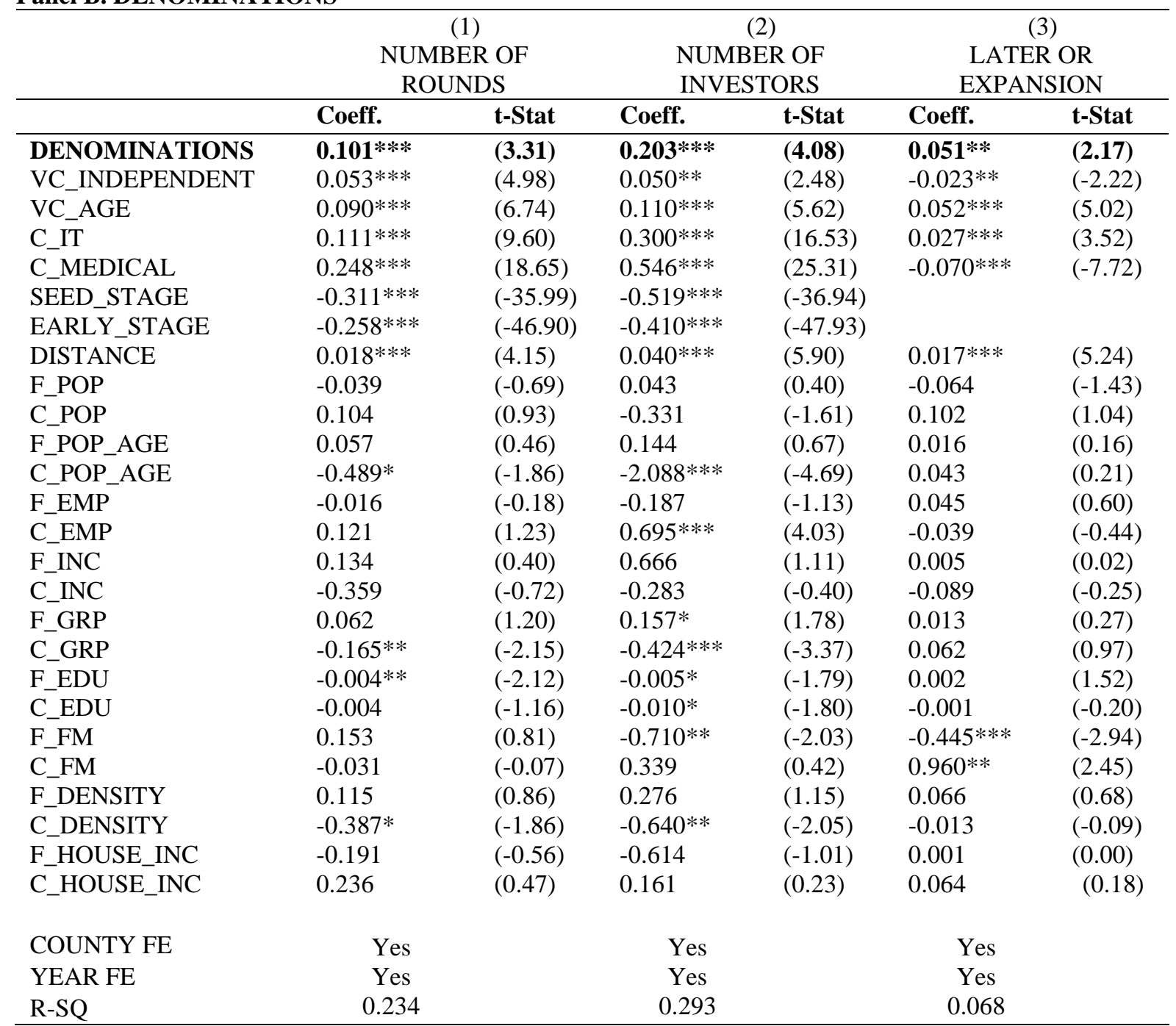


Table 4

Instrumental Variable Regressions

This table presents instrumental variable (IV) regression analyses of religiosity and VC investment characteristics measuring risk taking. Panel A gives the results for number of rounds, panel B for number of investors, and panel $\mathrm{C}$ for later or expansion stage. The first stage regresses religiosity measures, i.e. (DENOMINATIONS_INT, ADHERENTS_INT), on the instrumental variable (lagged three-year religiosity measure and total population in panels A and C, and lagged three-year proportion of white population in a VC county (panel B). The results for the first-stage regression are available upon request. The second stage regresses VC investment characteristics measuring risk taking on the fitted value of religiosity measures from the first stage. All regressions include constant, deal, and company county characteristics, county and year fixed effects. Standard errors are clustered by VC firm. The sample includes all round-by-round VC investments in portfolio firms from 1980 through 2014. The sample size consists of 91,020 observations in panels A and B, and 90,569 in panel C. All variables are as defined in Appendix Table AI. $* * *, * *$, and $*$ denote $1 \%, 5 \%$, and 10\% significance levels, respectively.

\begin{tabular}{|c|c|c|}
\hline & $(1)$ & $(2)$ \\
\hline \multicolumn{3}{|l|}{ Panel A. Number of Rounds } \\
\hline & $\begin{array}{l}\text { Coeff. } \\
\text { (t-Stat) }\end{array}$ & $\begin{array}{l}\text { Coeff. } \\
\text { (t-Stat) }\end{array}$ \\
\hline ADHERENTS_FITTED_VALUE & $\begin{array}{l}0.093 * * \\
(2.09)\end{array}$ & \\
\hline DENOMINATIONS_FITTED_VALUE & & $\begin{array}{l}0.100 \text { *** } \\
(3.29)\end{array}$ \\
\hline FIRST-STAGE F-STATISTICS P-VALUE & 0.000 & 0.000 \\
\hline SECOND-STAGE HANSEN J & 0.313 & 1.451 \\
\hline \multicolumn{3}{|l|}{ Panel B. Number of Investors } \\
\hline ADHERENTS_FITTED_VALUE & $\begin{array}{l}0.169 * * \\
(2.31)\end{array}$ & \\
\hline DENOMINATIONS_FITTED_VALUE & & $\begin{array}{l}0.195 * * * \\
(3.66)\end{array}$ \\
\hline FIRST-STAGE F-STATISTICS P-VALUE & 0.000 & 0.000 \\
\hline SECOND-STAGE HANSEN J & 0.473 & 0.927 \\
\hline \multicolumn{3}{|l|}{ Panel C. Later and Expansion } \\
\hline ADHERENTS_FITTED_VALUE & $\begin{array}{l}0.101^{*} \\
(1.77)\end{array}$ & \\
\hline DENOMINATIONS_FITTED_VALUE & & $\begin{array}{l}0.052 * * \\
(2.20)\end{array}$ \\
\hline FIRST-STAGE F-STATISTICS P-VALUE & 0.000 & 0.000 \\
\hline SECOND-STAGE HANSEN J & 0.217 & 0.085 \\
\hline
\end{tabular}


Table 5

Robustness - with VC Firm FEs

This table presents OLS regression analyses of religiosity on number of rounds in column (1), number of investors in column (2), and on stage of company development in column (3). Panel A measures religiosity using ADHERENTS, and Panel B using DENOMINATIONS. All regressions include constant, deal, and company county characteristics, VC firm, and year fixed effects. Standard errors are clustered by VC firm. The sample includes all round-by-round VC investments in portfolio firms from 1980 through 2014. The sample size consists of 91,020 observations. All variables are as defined in Appendix Table AI. ***, $* *$, and * denote $1 \%, 5 \%$, and $10 \%$ significance levels, respectively.

\begin{tabular}{|c|c|c|c|c|c|c|}
\hline \multicolumn{7}{|l|}{ Panel A. ADHERENTS } \\
\hline & \multicolumn{2}{|c|}{$(1)$} & \multicolumn{2}{|c|}{ (2) } & \multicolumn{2}{|c|}{ (3) } \\
\hline & \multicolumn{2}{|c|}{ NUMBER OF ROUNDS } & \multicolumn{2}{|c|}{ NUMBER OF INVESTORS } & \multicolumn{2}{|c|}{ LATER OR EXPANSION } \\
\hline & Coeff. & t-Stat & Coeff. & t-Stat & Coeff. & t-Stat \\
\hline ADHERENTS & 0.118 & (1.19) & 0.296* & $(\mathbf{1 . 6 7 )}$ & 0.021 & $(0.24)$ \\
\hline CONTROLS & Yes & & Yes & & Yes & \\
\hline VC FIRM FE & Yes & & Yes & & Yes & \\
\hline COUNTY FE & Yes & & Yes & & Yes & \\
\hline YEAR FE & Yes & & Yes & & Yes & \\
\hline R-SQ & 0.314 & & 0.331 & & 0.114 & \\
\hline \multicolumn{7}{|c|}{ Panel B. DENOMINATIONS } \\
\hline & \multicolumn{2}{|c|}{$(1)$} & \multicolumn{2}{|c|}{ (2) } & \multirow{2}{*}{\multicolumn{2}{|c|}{$\begin{array}{c}(3) \\
\text { LATER OR EXPANSION }\end{array}$}} \\
\hline & \multicolumn{2}{|c|}{ NUMBER OF ROUNDS } & \multicolumn{2}{|c|}{ NUMBER OF INVESTORS } & & \\
\hline & Coeff. & t-Stat & Coeff. & t-Stat & Coeff. & t-Stat \\
\hline DENOMINATIONS & 0.088* & (1.69) & $0.149 *$ & (1.77) & $0.119 * * *$ & (2.94) \\
\hline CONTROLS & Yes & & Yes & & Yes & \\
\hline VC FIRM FE & Yes & & Yes & & Yes & \\
\hline COUNTY FE & Yes & & Yes & & Yes & \\
\hline YEAR FE & Yes & & Yes & & Yes & \\
\hline R-SQ & 0.309 & & 0.360 & & 0.160 & \\
\hline
\end{tabular}


Table 6

Portfolio Company Religiosity and VC Investment Characteristics - Falsification Test

This table presents OLS regression analyses of religiosity on number of rounds in column (1), number of investors in column (2), and stage of company development in column (3). Panel A measures portfolio company religiosity using ADHERENTS, and Panel B using DENOMINATIONS. All regressions include constant, deal, and company county characteristics and year and VC firm fixed effects. Standard errors are clustered by VC firm. The sample includes all round-by-round VC investments in portfolio firms from 1980 through 2014. The sample size consists of 91,020 observations. All variables are as defined in Appendix Table AI. ***,**, and * denote 1\%, 5\%, and $10 \%$ significance levels, respectively.

Panel A. PORTFOLIO COMPANY ADHERENTS

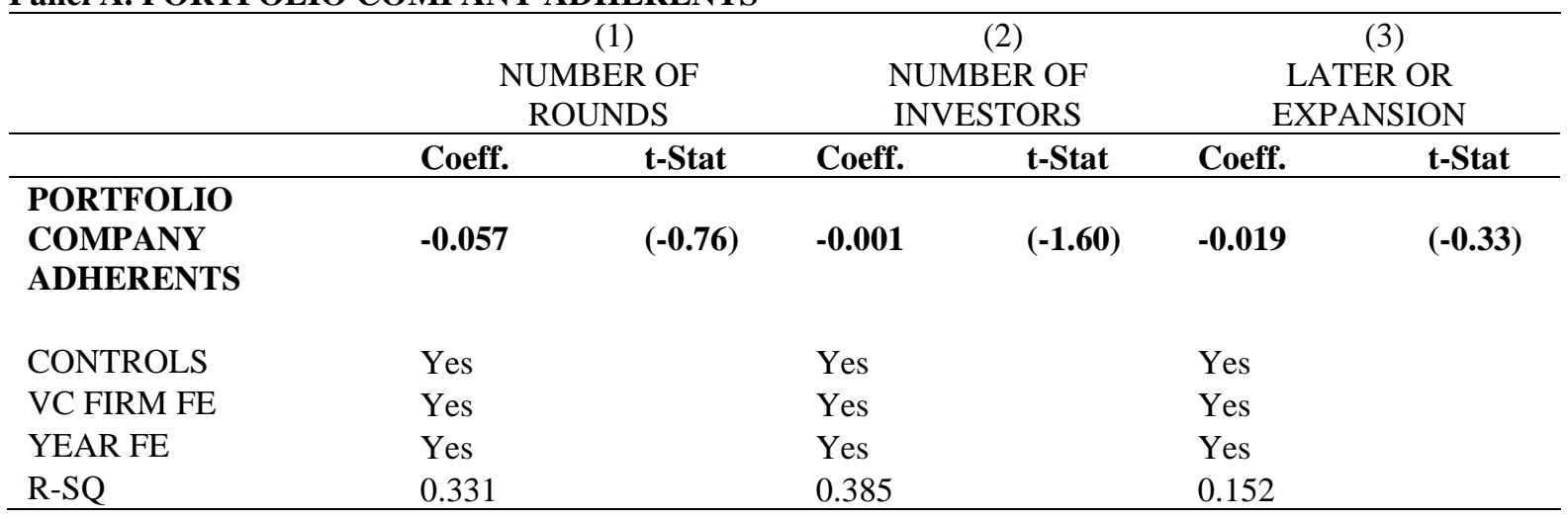

Panel B. PORTFOLIO COMPANY DENOMINATIONS

\begin{tabular}{|c|c|c|c|c|c|c|}
\hline & $\mathrm{N}$ & OS & & $\begin{array}{l}\text { R OF } \\
\text { ORS }\end{array}$ & & $\begin{array}{l}\text { OR } \\
\text { ON }\end{array}$ \\
\hline & Coeff. & t-Stat & Coeff. & t-Stat & Coeff. & t-Stat \\
\hline $\begin{array}{l}\text { PORTFOLIO } \\
\text { COMPANY } \\
\text { DENOMINATIONS }\end{array}$ & -0.068 & $(-1.33)$ & -0.056 & $(-0.69)$ & -0.006 & $(-0.17)$ \\
\hline $\begin{array}{l}\text { CONTROLS } \\
\text { VC FIRM FE } \\
\text { YEAR FE } \\
\text { R-SQ }\end{array}$ & $\begin{array}{l}\text { Yes } \\
\text { Yes } \\
\text { Yes } \\
0.331\end{array}$ & & $\begin{array}{l}\text { Yes } \\
\text { Yes } \\
\text { Yes } \\
0.389\end{array}$ & & $\begin{array}{l}\text { Yes } \\
\text { Yes } \\
\text { Yes } \\
0.152\end{array}$ & \\
\hline
\end{tabular}

Panel C. SAME COUNTY

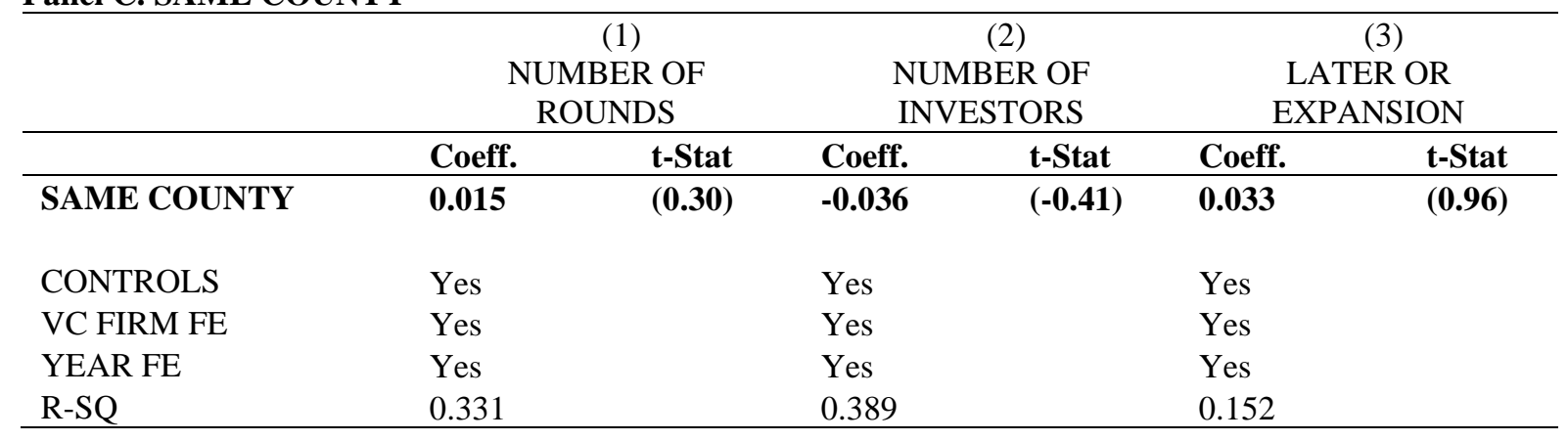

